The third paper on steel was by Mr. J. R. Ravenhill, and gave an account of the improvements which have recently been made in mild steel castings. Many portions of machinery and steam-engines which till quite recently were invariably made of cast iron can now be formed of cast steel, with the attendant advantages of gain in strength and saving in weight.

Perhaps the most interesting paper of the four was that by M. Berrier Fontaine, the eminent French naval architect, "On the Use of Mild Steel for the Construction of the Hulls of Ships in the French Navy." The French were undoubtedly the first to introduce this material into the national navy; but though their experience of it is longer than our own, they do not seem to have acquired the same confidence in its use which is now felt in this country. For instance, we are in the habit of constructing the entire hulls of ships, incluaing the below-water plating, of steel; the French, on the other hand, continue to use iron for all work which has to be exposed to the action of sea water. The reason advanced is that they find that steel when immersed in salt water corrodes with far greater rapidity than iron. M. Berrier Fontaine quotes as examples two gunboats, the Ekee and the Tromblon, the hulls of which, completely steel-plated, have both given proof of rapid and deep corrosion. "The Tromblon was launched at Toulon on January 20, 1875, and remained afloat till October 27 of the same year. During that period of nine months it was found necessary to dock her three times, that it is to say, about every two months to ipaint the hull, the plates being rapidly and deeply attacked, especially in the neighbourhood of the waterline. The progress of this corrosion went on with such unusual rapidity, that when the time came to pass the Tromblon into the reserve it was thought necessary to haul her on to a slip instead of keeping her afloat." The whole subject of the corrosion of steel plates is at present involved in great mystery, and no two authorities seem able to agree about the cause. In the English Admiralty it is commonly believed that it is due to the presence on the surface of the plates of portions of black oxide, which constitute with the steel so many active galvanic couples, which of course rapidly promote corrosion, and hence great care is now taken to remove all traces of this oxide before the plates are coated. Whatever may be the cause, it is perfectly certain that the experience of English builders does not tally with that of M. Berrier Fontaine in this particular. Certain cases of corrosion have no doubt occurred in this country, and the hull of the Iris is an example in point; but as far as present experience goes such cases are the exception instead of the rule.

M. Berrier Fontaine gives an interesting account of the tools and other plant used in the French dockyards for the working of steel. He describes also the early difficulties which the workmen experienced, all of which have been successfully overcome. As regards the process of manufacture adopted in France, it appears that equally good results are obtained from the Bessemer and the Siemens methods, so much so that when contracts are given out it is never specified that the material is to be prepared by either of the two processes. In some works the Siemens system is employed for the superior sorts of steel, and the Bessemer process reserved for inferior descriptions, such as rails, while in other works exactly the opposite takes place. In this country, on the contrary, it is almost universally the rule to specify the Siemens process for the production of mild steel plates for ship-building and for boiler purposes.

\section{DUNES AND MOVING SANDS}

IN a communication made to the Russian Society of Naturalists, M. Sokoloff has given a description of the dunes which are seen close by Sestroryetsk, at the eastern end of the Gulf of Finland. The whole of the isthmus between the Gulf and the basin of Sestroryetsk is covered with dunes which have a double origin. Those which are close by the sea-shore are old shore-ridges, mostly covered with vegetation, parallel to one another, and having each the form of a straight line, while those which are situated more east are true dunes, built up of sand driven by the wind. They have the direction north and south, and they reach the height of a hundred feet. Several of them are quite covered with pine-forests and with moss, while others are almost quite naked. The latter are constantly brought into motion by the west wind, and south of the Sestra River a high dune will shortly cover the houses of the working men of the Sestroryetsk manufactory. This dune, about 700 feet broad, has already covered several houses, and it is always advancing further, forming smaller parallel dunes fifteen feet high; its western side is covered with numerous excavations, from which the wind has taken the sand to move it further east. M. Sokoloff, while agreeing with the well-known classification of dunes established by the explorer of Sahara, M. Vatonne, thinks that the dunes of the deserts, which owe their origin to the action of wind, might be very easily distinguished from the mostly lower ridges which appear on the sea-shores under the influence of waves, these last usually having the form of straight lines, whilst the true dunes always have a semicircular form. M. Severtzoff observed after this communication that in the steppe of Kyzylkoum, true dunes often have the same form of parallel, quite straight ridges. However, having at their origin a circular form which is so characteristic of the barkhans of the steppe, they lose by and by this form, and several smaller dunes, uniting together at their ends, take the form of a long straight ridge perpendicular to the prevailing direction of wind. M. Moushketoff, who has made a close acquaintance with the sands of Central Asia, observed that these sands, which are all sporadic, being spread among older formations, are very different as to their extent, their stratigraphical and petrographical characters, and their origin. They might be subtivided into three different classes :-I. Those which have a marine origin and which might be observed on the south-eastern shores of Lake Aral, and especially in the Kara-koum steppe. They are about 250 yards and 70 feet high, and mostly parallel to the shore. They are typical marine dunes, but their extension closely depends upon the extension of the Aralo-Caspian formation, the fossils of which are always found broken in these sands. 2. The fluvial dunes, which are very common in the valleys of the Amou, Syr, Sourkhan, and others; their height rarely exceeds ro to fifteen feet, and their length is from roo to 150 feet ; their sand is steelgray, and contains gypsum and clay. 3. The barkhans are subaerial formations; they prevail in the central part of the steppe Kyzyl-koum, but are rather rare in the Kara-koum steppe. They have the form of a sickle, and are somewhat conical, their maximum height being as much as 20 to 30 feet; their slopes are very different, that which is under the influence of the wind having an inclination from 5 to I3 degrees, whilst the other slope is short and steep, the inclination reaching sometimes as much as 43 degrees; they consist of a dirty-yellow or red sand, owing to their origin in the Tertiary sandstone, or sometimes in other harder rocks, as for instance, in the valley of the Ili River. Sometimes typical barkhans are met with among dunes, being a secondary formation arising out of the marine dunes. As to the plantations of trees on dunes, $M$. Moushketoff thinks that it would be far more rational first to determine whence the sand is brought by the wind, and to make the plantations of trees or bushes, according to the chemical character of the sand on this place, instead of making them on the dunes themselves.

\section{UNIVERSITY AND EDUCATIONAL INTELLIGENCE}

MANChester.-We learn that the Council of the Owens College proposes shortly to establish an independent Chair of Applied Mathematics.

EDINBURGH.-The tercentenary of the University of Edin. burgh will be celebrated in 1883 . The senatus are to invite representatives from other universities to be present; they also propose to bring out a history of the University during the first 300 years.

THE winter session of the College of Agriculture, Downton, Salisbury, was brought to a close on Wednesday, when the prizes were presented by Earl Nelson, who dwelt at considerable length on the present state and future prospects of British agriculture, taking a very hopeful view of the latter. The High Sheriff of Wilts warmly advocated such a combination of science with practice as was in vogue at the College. The Scholarship offered for competition amongst students who have completed their first year at the College was aw arded to Mr. Louis Johnstone, son of Sir Harcourt Johnstone, Bart., Hockurss Hall, Scarborough, the Hon. Victor A. N. Hood proxime accessit.

\section{SOCIETIES AND ACADEMIES LONDON}

Royal Society, March 31.-" Permanent Molecular Torsion of Conducting Wires produced by the Passage of an Electric Current," by Prof. D. E. Hughes, F.R.S. 